The Bangladesh V eterinarian (2016) 33(2) : $71-77$

\title{
Serum testosterone concentration in surgically castrated Black Bengal goats
}

\author{
M Hasan, MAH Miah, TA Rosy, PK Jha1 and NS Juyena* \\ Department of Surgery and Obstetrics, Faculty of Veterinary Science, Bangladesh \\ Agricultural University, Mymensingh-2202, Bangladesh
}

\begin{abstract}
A bstract
The experiment was carried out to detect the blood serum testosterone concentration after orchiectomy in Black Bengal bucks (Capra hircus). Twelve apparently healthy bucks of 8 10 months old were randomly divided into two groups. Group A were castrated surgically through open uncover method and group $B$ remained intact. Local analgesia ( $2 \%$ lidocaine hydrochloride) @ $0.5 \mathrm{~mL}$ per spermatic cord and $0.5 \mathrm{~mL}$ at the tip of each scrotum were applied initially in all bucks. After aseptic preparation, incision was given at the tip of the scrotum and tunica vaginalis was incised to exteriorize the testis. Anchoring was done at the spermatic cord foll owed by orchiectomy. The scrotal raphe was incised to reach the other testis and the same procedure was followed. Blood samples were collected from jugular vein before orchiectomy and on day 30 . In the castrated bucks, serum testosterone concentration was significantly $(\mathrm{P}<0.01)$ decreased from day $0(6.1 \pm 0.2$ $\mathrm{ng} / \mathrm{mL}$ ) to day $30(0.6 \pm 0.0 \mathrm{ng} / \mathrm{mL})$, which confirmed the efficacy of castration. (Bangl. vet. 2016. Vol. 33, No. 2, 71- 77)
\end{abstract}

\section{Introduction}

Castration of male animals is the removal of the testicles or making the testicles nonfunctional (A bid and Al-Baghdady, 2013). Castration can involve obliteration of blood supply to the testes by crushing the blood vessels, cutting, vaccinating or elevating temperature of the testes (Frandson and Spurgeon, 1992). Castration is performed to prevent the production of androgens and spermatogenesis (Baird and Wolfe, 1998; Gilbert and Fubini, 2004), to prevent unwanted mating and mounting and injuries accompanied or to treat testicular or inguinal pathology (Searle et al., 1999; Price et al., 2005; Edwards, 2008), to decrease aggressiveness and to make the animal docile for easy management (Kent et al., 1996; Stafford, 2007). In food animals, castration can improve quality and taste of meat, and feed efficiency (Thompson, 2000; Anderson, 2007) and reduce goaty smell in the meat (Merkel and Dawson, 2008). Goat meat is otherwise tainted if kids are slaughtered after more than four months of age (Devendra and McLeroy, 1988). Methods of castration can be classified into physical, chemical, and hormonal.

1Scientist (S-1), Nepal Agricultural Research Council (NARC), National Animal Science Research Institute(NASRI), A nimal Breeding Division, Khumaltar, Lalitpur, Nepal

*Corresponding author:- E-mail: juyenahabib@yahoo.com 
Testes act as the main source of testosterone (Starr et al., 2012). The present research determined blood serum testosterone concentrations after castration.

\section{M aterials and Methods}

\section{Ethical statement}

Orchiectomy was done aseptically. Local analgesia was done prior to orchiectomy. Painkiller was administered as post-castration pain management.

\section{Experimental site}

The research was carried out in the Research A nimal Farm Laboratory, Department of Surgery and Obstetrics, Bangladesh Agricultural University, Mymensingh, from July 2016 to N ovember 2016.

\section{Study population}

Twelve male Black Bengal goats (bucks) 8 - 10 months old were purchased from local market. The bucks weighed $12-15 \mathrm{~kg}$ and no visible abnormalities or disease were detected. The bucks were kept in quarantine for 14 days and were supplied with grass, concentrate feed and water. The goat-shed was regularly washed and disinfected with $0.1 \%$ potassium permanganate solution. Ivermectin $0.2 \mathrm{mg} / \mathrm{kg}$ was injected subcutaneously to each buck. Tetanus toxoid vaccine and PPR vaccine were administered to each buck before the experiment.

\section{Experimental protocol}

The bucks were acclimatized and divided into two groups of 6, Group A were castrated, group B were control. ELISA was used to determine the blood serum testosterone concentrations.

\section{O bservation of clinical parameters}

Rectal temperature, heart rate and respiration rate were measured before orchiectomy (day 0 ) on day 1 to 7 , on day 15 and day 30 post-castration.

\section{O rchiectomy procedure}

Open uncover method was applied. Initially local analgesia was done using $2 \%$ lidocaine hydrochloride @ $0.5 \mathrm{~mL}$ per spermatic cord and @ $0.5 \mathrm{~mL}$ at the tip of the scrotum. The operation site was shaved, scrubbed with soapy water and painted with tincture of iodine. After aseptic preparation, incision was made at the tip of scrotum and tunica vaginalis was incised. The testis was pressed firmly and spermatic cord was exteriorized. Spermatic cord was anchored using chromic catgut no. 1 followed by orchiectomy distal to epididymis. The scrotal raphe was incised to reach the other testis and same procedure was followed. Antibiotics (Procaine penicillin 30 lac IU and Benzyl penicillin 10 lac IU; Pronapen ${ }^{\circledR}$, Renata Ltd., Bangladesh) antihistaminic (Pheniramine maleate @ 1.0 mg/ Kg body weight; Asta-vet ${ }^{\circledR}$, The Acme Laboratories 
Ltd., Bangladesh) and anti-inflammatory drugs (Ketoprofen dosed @3.0 mg/ Kg body weight; Ketovet ${ }^{\circledR}$, Techno Drugs Ltd., Bangladesh) were administered.

\section{Hormonal assay of testosterone using ELISA techni que}

Blood serum collection

Briefly, $2 \mathrm{~mL}$ blood samples were collected from left jugular vein following aseptic measures, before orchiectomy and on day 30 using vacuum blood collection tube. Blood samples were centrifuged @ 3000 rpm for 30 minutes. Afterwards, serum were collected in Eppendorf tubes and kept at $-20^{\circ} \mathrm{C}$.

\section{ELISA procedure}

Serum samples were equilibrated at room temperature for about 30 minutes. The testosterone ELISA kit was purchased from Nova Tedmmunodiagnostica $\mathrm{GmbH}$ (Germany). For testosterone assay, biotinylated antibody, enzyme-antigen conjugate and a native antigen containing serum were used as the essential reagents. The biotinylated antibody is the anti-testosterone biotinylated purified rabbit IgG conjugate. Horseradish peroxidase is the enzyme-antigen conjugate. Standard instructions were followed. Testosterone concentration was measured in $\mathrm{ng} / \mathrm{mL}$. Calculations were done using the formula $y=a+b \times x$ from a standard curve (Fig. 1) with seven standards supplied with the testosterone ELISA kit box. At $450 \mathrm{~nm}$, the optical density (OD) values of the samples and standards were determined using the spectrophotometer (ELISA reader) UItra Microplate reader (Biotek Instruments, Inc., Winooski, USA).

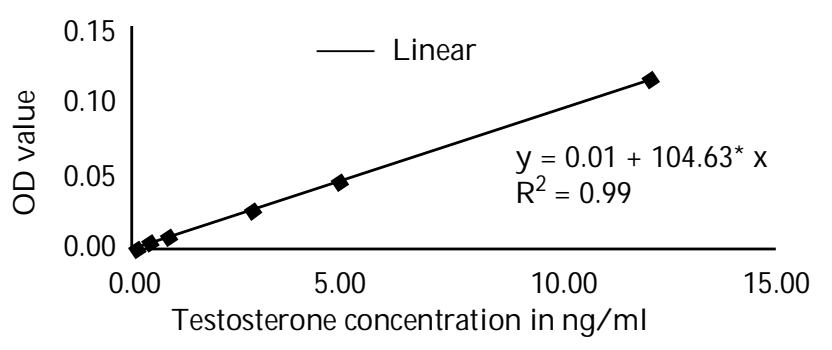

Fig. 1: Standard curve for the determination of testosterone concentration in serum (OD = Optical density; $R^{2}=$ Coefficient of determination).

\section{Statistical analysis}

One way analysis of variance (ANOVA) was applied, using the software IBM SPSS Statistics, Version 20. The level of significance was considered at $P \varangle 0.05$.

\section{Results and Discussion}

For many years, orchiectomy has been a standard method for sterilization of male animals. However, several drawbacks have been associated with this procedure such as high cost, time consumption, need for postoperative care, risk of post-operative 
complications, small-scale application, the requirement of anaesthesia, medical equipment, a sterile surgical suite, a trained Veterinary Surgeon, and Iong recovery time (Jana and Samanta, 2007).

Rectal temperature, heart rate and respiration rate before and after orchiectomy in the two groups are presented in Table 1, 2 and 3, respectively. There were slight increases in rectal temperature, heart rate and respiration rate immediately after orchiectomy in group $A$, but these deviations were insignificant $(P>0.05)$ when compared to the control. Previous studies reported that there is an increasing cortisol response to castration with increasing age (King et al., 1991; Robertson et al., 1994). Regardless of the castration technique and the age of the patient, all ruminants benefit from the use of systemic analgesia (e.g., a non-steroidal anti-inflammatory drug - NSAID), and/ or a local anaesthetic (Stafford et al., 2002; Stafford and Mellor, 2005). The fact that temperature, heart rate and respiratory rate did not differ significantly between castrated and control suggests that pain was well controlled.

Table 1: Rectal temperatures ( $\left.{ }^{\circ} \mathrm{F}\right)$ (M ean \pm SE) of Black Bengal bucks

\begin{tabular}{l|c|c}
\hline Days & Group A & Group B \\
\hline 0 & $102.7 \pm 0.3$ & $103.1 \pm 0.2$ \\
1 & $103.9 \pm 0.6$ & $103.1 \pm 0.1$ \\
2 & $103.2 \pm 0.2$ & $103.1 \pm 0.1$ \\
3 & $102.9 \pm 0.4$ & $103.3 \pm 0.2$ \\
4 & $102.6 \pm 0.2$ & $103.1 \pm 0.2$ \\
5 & $102.8 \pm 0.4$ & $103.4 \pm 0.2$ \\
6 & $102.9 \pm 0.3$ & $103.1 \pm 0.2$ \\
7 & $102.9 \pm 0.4$ & $103.1 \pm 0.1$ \\
15 & $103.0 \pm 0.5$ & $103.2 \pm 0.3$ \\
30 & $102.9 \pm 0.3$ & $103.0 \pm 0.2$ \\
\hline
\end{tabular}

Table 2: Heart rate (mean $\pm \mathrm{SE}$ ) of Black Bengal bucks

\begin{tabular}{|c|c|c|c|}
\hline Days & Group A & Group B & \\
\hline 0 & $105.3 \pm 4.8$ & $114.0 \pm 2.7$ & \\
\hline 1 & $111.7 \pm 5.4$ & $103.0 \pm 2.7$ & \\
\hline 2 & $111.0 \pm 1.5$ & $108.7 \pm 3.5$ & \\
\hline 3 & $106.0 \pm 5.3$ & $103.0 \pm 8.6$ & \\
\hline 4 & $112.0 \pm 4.0$ & $105.0 \pm 2.7$ & \\
\hline 5 & $107.3 \pm 2.9$ & $110.7 \pm 3.5$ & \\
\hline 6 & $105.3 \pm 6.0$ & $100.0 \pm 4.2$ & \\
\hline 7 & $107.0 \pm 5.5$ & $107.7 \pm 6.2$ & \\
\hline 15 & 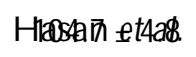 & $100.0 \pm 5.3$ & 75 \\
\hline 30 & $108.0 \pm 2.3$ & $102.0 \pm 4.3$ & \\
\hline
\end{tabular}

Table 3: Respiratory rate (Mean $\pm \mathrm{SE}$ ) of Black Bengal bucks 


\begin{tabular}{l|c|c}
\hline Days & Group A & Group B \\
\hline 0 & $30.3 \pm 3.5$ & $26.7 \pm 3.71$ \\
1 & $38.3 \pm 3.8$ & $24.0 \pm 0$ \\
2 & $34.0 \pm 2.5$ & $25.7 \pm 2.9$ \\
3 & $30.7 \pm 4.2$ & $25.3 \pm 3.8$ \\
4 & $26.3 \pm 5.8$ & $27.0 \pm 4.0$ \\
5 & $26.3 \pm 2.4$ & $23.3 \pm 3.3$ \\
6 & $28.3 \pm 0.3$ & $26.0 \pm 5.3$ \\
7 & $24.0 \pm 2.9$ & $25.0 \pm 3.5$ \\
15 & $24.3 \pm 3.4$ & $22.0 \pm 3.0$ \\
30 & $25.5 \pm 2.5$ & $24.3 \pm 2.7$ \\
\hline
\end{tabular}

The testosterone concentration in serum markedly decreased on day 30 postcastration (Fig. 2). The serum testosterone concentration in group A dedined significantly $(\mathrm{P}<0.01)$ from $6.1 \pm 0.2 \mathrm{ng} / \mathrm{mL}$ on day 0 before to $0.55 \pm 0.0 \mathrm{ng} / \mathrm{mL}$ on day 30 after castration. In the control group $B$, the testosterone concentration in the blood serum was $6.4 \pm 0.2 \mathrm{ng} / \mathrm{mL}$ and $6.5 \pm 0.3 \mathrm{ng} / \mathrm{mL}$ on day 0 and day 30, respectively. The difference on day 30 was significant $(\mathrm{P}<0.01)$. Previous studies gave similar results (Cai et al., 2015; Sosic-Jurjevic et al., 2012).

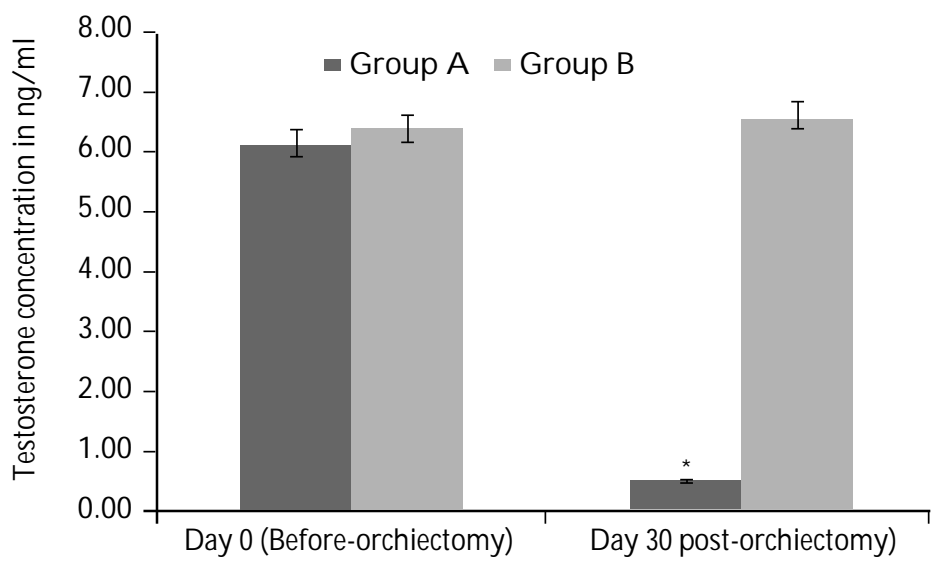

Fig. 2: Testosterone concentration in blood serum before orchiectomy on day 0 and on day 30 post-orchiectomy.

The data are expressed as mean $\pm \mathrm{SEM}$; $* \mathrm{P} \varangle 0.05$, significantly different as compared to group B on day 30.

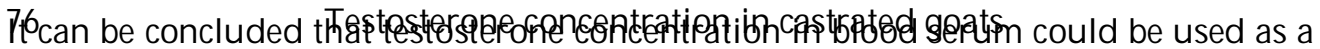
major determinant in evaluating the efficacy of castration in Black Bengal bucks.

References 
A bid TA, Al-Baghdady EF 2013: Evaluation of pinhole castration technique in Iraqi Black local breed bucks: Morphological and Histological Assessment. Journal of A nimal and V eterinary A dvances 12 423-427.

Anderson N 2007: Castration of calves. Fact Sheet A nimal Science, Ministry of Agriculture food and Rural Affairs, Ontario, Canada pp. 1-8.

Baird AN, Wolfe DF 1998: Castration of the Normal Male. In: Large Animal Urogenital Surgery, Wolfe DF and Moll HD (Eds) 2nd Edn. Williams and Wilkins, Baltimore, MD, USA pp. 295-301.

Cai Z, Zhang L, Jiang X, Sheng Y, Xu N 2015: Differential miRNA expression profiles in the longissimus dorsi muscle between intact and castrated male pigs. Research in V eterinary Science 99 99-104.

Devendra C, McLeroy GB 1988: Goat and Sheep Production in the Tropics. ELBS/ Longman, London, UK.

Edwards JD 2008: Pathologic conditions of the stallion reproductive tract. Animal Reproduction Science, 107 197-207.

Frandson RD, Spurgeon TL 1992: Anatomy and physiology farm animal (5th edn). Lea and Febiger, USA, pp. 572.

Gilbert RO, Fubini SL 2004: Surgery of the Bovine ReproductiveSystem and Urinary Tract. In: Farm Animal Surgery, Fubini, SL, Duchorme (Eds.). Saunders, USA pp. 351-427.

Jana K, Samanta PK 2007: Sterilization of male stray dogs with a single intratesticular injection of calcium chloride: a dose-dependent study. Contraception 75 390-400.

Kent JE, Thrusfield MV, Robertson IS, Molony V 1996: Castration of calves: A study of methods used by farmers in the United Kingdom. V eterinary R ecord 138 384-387.

King BD, Cohen RDH, Guenther CL, Janzen ED 1991: The effect of age and method of castration on plasma cortisol in beef calves. Canadian Journal of A nimal Science $\mathbf{7 1}$ 257-263.

Merkel RC, Dawson L 2008: Castration of sheep and goats. Technical Bulletin No. 18, Ethiopia Sheep and Goat Productivity Improvement Program (ESGPIP) pp. 1-12.

Price J, Eager RA, Welsh EM, Waran NK 2005: Current practice relating to equine castration in the UK. Research in V eterinary Science 78 277-280.

Robertson IS, Kent JE, Molony V 1994: Effect of different methods of castration on behaviour and plasma cortisol in calves of three ages. Research in V eterinary Science 56 8-17.

Searle D, Dart AJ, Dart CM, Hodgson DR 1999: Equine castration: Review of anatomy, approaches, techniques and complications in normal, cryptorchid and monorchid horses. A ustralian V eterinary Journal 77 428-434. 
Sosic-Jurjevic B, Filipovic B, Renko K, Ajdzanovic V, Manojlovic-Stojanoski M, Milosevic V, KohrleJ 2012: Orchidectomy of middle-aged rats decreases liver deiodinase 1 and pituitary deiodinase 2 activity. Journal of Endocrinology 215 247-256.

Stafford KJ, Mellor DJ 2005: The welfare significance of the castration of cattle: a review. N ew Zeal and V eterinary Journal $\mathbf{5 3}$ 271-278.

Stafford KJ 2007: Alleviating the pain caused by the castration of cattle. The V eterinary Journal 173 333-342.

Stafford KJ, Mellor DJ, Todd SE, Bruce RA, Ward RN 2002: Effects of local anesthesia plus a non-steroidal anti-inflammatory drug on the acute response of calves to five different methods of castration. Research in V eterinary Science 73 61-70.

Starr C, Taggart R, Evers C 2012: Animal structure and function biology. The unity and diversity of life. $13^{\text {th }}$ edn. Cengage Learning, UK.

Thompson DL 2000: Immunization against GnRH in male species (Comparative aspects). A nimal Reproduction Science 60 459-469. 